\title{
Microbial Incidence and Antibiotic susceptibility for Bacterial isolates in The Mobile Phone of Healthcare workers and University Employments in Basrah City
}

\author{
Rana Mohammad Abd-ulnabi (D), Zuhair G. Alshaheen (D) and \\ Rafeef A. Abdul-jabbar* (iD) \\ Department of Clinical Laboratory Sciences, College of Pharmacy, University of Basra, Iraq.
}

\begin{abstract}
The mobile phones come to be an important device all people use it for communication and phones can be contaminated with bacterial isolates. this study tries to do a little investigation about kinds and percent of pathogenic bacteria and the detection of some antibiotic resistance one and difference between that found in the healthcare worker's mobile phone and peoples who work out of that field. Samples collection were done using mobile phones belongs to healthcare workers and Basra University employments. Swabs were cultured on different media then the suspected colonies were identified by recognizing the morphology of colonies, staining with Gram's stain then tested with biochemical tests. Our study shows bacterial isolates in all the screened mobile phone, The highest proportions were recorded by Bacillus spp (66\%) and Pseudomonas spp (56\%) while the lowest proportions were Staphylococcus aureus (8\%) and Candida spp (12\%). And there was a significant difference in the kinds and percent of bacterial isolates between the healthcare workers and employments mobile phones, besides the appearance of Cefotaxime and Cefatizoxime resistance Proteus sp. and Trimethoprim + Sulfamethoxazole resistance Klebsiella spp. also the intermediate susceptibility to the different antibiotic was shown in all isolates. All the mobile phones can be contaminated by various kinds of bacteria some of these were resistant to some antibiotics and there was a significant difference in the percent and kinds of bacterial isolates between the health care worker and people who work out of this field.
\end{abstract}

Keywords: Mobile phone, healthcare workers, antibiotic susceptibility, pathogenic bacteria

*Correspondence: rafeefamir@gmail.com; 07802410151

(Received: June 19, 2020; accepted: September 10, 2020)

Citation: Abd-ulnabi RM, Alshaheen ZG, Abdul-jabbar RA. Microbial Incidence and Antibiotic susceptibility for Bacterial isolates in The Mobile Phone of Healthcare workers and University Employments in Basrah City. J Pure Appl Microbiol. 2020;14(3):18631870. doi: 10.22207/JPAM.14.3.25

(C) The Author(s) 2020. Open Access. This article is distributed under the terms of the Creative Commons Attribution 4.0 International License which permits unrestricted use, sharing, distribution, and reproduction in any medium, provided you give appropriate credit to the original author(s) and the source, provide a link to the Creative Commons license, and indicate if changes were made. 


\section{INTRODUCTION}

The healthcare workers commonly have an inclusive knowledge about the infection prevention, assessment management of the patients as compared with peoples who work out of that field, despite that many studies were done for nosocomial infections that can be caused by extrinsic factors, such as transferring of pathogens from the hands of medical staff, contaminated medical or even non-medical equipment to other people, and one of the most used equipment by the medical staff, as well as patients, is the mobile phone that's because the latter has come to be an important device all people can use it to communicate in everyday life and are often used largely in all places ${ }^{1,2}$. In Iraq, in 2018 there were 36.47 million mobile subscriptions ${ }^{3}$.

The mobile phones in most of the time found in contact with the hands of medical staff in hospitals, phones can be used by them for imaging results, drugs therapeutic, laboratory and other work-related subjects ${ }^{4}$. Therefore they can be contaminated by bacteria, simply because mobile phones are not managed cleanly, and there are no guidelines for controlling bacterial contamination on mobile phones ${ }^{1}$.

Really that is not limited in healthcare places and peoples who present there, the Studies revealed that the contamination of phones can come from many things like handbag or skin of human, phone pocket, bags, and food particles, etc. ${ }^{5}$ The continuous handling and the heat produced by phone and hands sweat generates an ideal breeding situation for all types of bacteria that are found on our skin ${ }^{6}$.

In the current study, we try to do a little study about the effect of the site and the pattern of work on the kinds and percent of pathogenic bacterial isolates that are found in the mobile phone for both healthcare workers and peoples who work out of that field, and if there is an antibiotic-resistant bacteria on that phone.

\section{MATERIALS AND METHODS Designing of the study}

Our study was performed in the period from March to June 2019, samples collection were done using fifty volunteer mobile phones at Basra province, half of them were the healthcare workers in Al-Sadr Teaching Hospital. While the other half collected from the employments (administrative staff at the Deanships of the University of Basra colleges). The volunteers are from both sexes with ages from 20 to 45 years old and all asked about the cleaning of their mobile phone and interim from the latest cleaning for the phones.

\section{Sampling}

By using moist sterile cotton swab the sample was taken from all sides of mobile phones after handling each phone with the aid of sterile gloves then each swab was placed in a tube with $3 \mathrm{ml}$ of tryptic soy broth and aerobically incubated at $37^{\circ} \mathrm{C}$ for $18-24$ hours $^{7}$.

\section{Isolation and Identification of isolates}

Different media including Blood agar, Nutrient agar, and MacConkey agar were used for culturing each swab and incubated overnight at $37^{\circ} \mathrm{C}$. and then by streaking on the identical media bacteria were isolated and purified ${ }^{8}$.

The suspected colonies were identified using Gram's staining, colony morphology, and appropriate biochemical tests, and their shapes, colors, and arrangements were observed under light microscope 9 .

For identification of Gram-positive cocci isolates that appeared as medium-sized circular, white or golden yellow with a smooth convex surface and entire edge and were either $\beta$-hemolytic on blood agar plates and grow on the Mannitol salt agar were positive for catalase that is Staphylococcus aureus (S. aureus) or Non-hemolytic on blood agar and grows on the Mannitol salt agar and catalase-positive that is Staphylococcus epidermidis.

As regards Gram-negative bacilli (lactose and non-lactose fermenters), Hydrogen Sulfide $\left(\mathrm{H}_{2} \mathrm{~S}\right)$ Production Test, the oxidase, catalase, triple sugar iron agar (TSI), indole, methyl red, Voges Proskauer, citrate (IMViC) and urease tests were carried out for their identification ${ }^{10}$.

An oxidase test was used to differentiate between Pseudomonas spp and Enterobacteriaceae $s p^{11}$.

\section{Antibiotic susceptibility}

Antibiotic susceptibility testing was performed for some of the identified isolates on Mueller-Hinton agar according to the standard recommendation of the National Committee for 
Clinical Laboratory Standards [N.C.C.L.,2000]. The resistance isolates were detected using some of the antibiotics disc shown in Table $(1)^{12}$.

\section{Statistical analysis}

The presence of a significant difference in the kind and percent of bacterial isolates in the mobile phone of a health care worker and university of Basrah employments was analyzed by utilizing a Chi-square test by using the 2010 Microsoft Office Excel ${ }^{13}$.

\section{RESULTS}

Fifty samples were obtained from the mobile phones of the volunteers, most of the volunteers don't clean their mobile phone continuously after using them in the work especially the healthcare workers, and there is no exact time interval between each cleaning time for their mobile phone almost they are clean when seems unclean.

All of the screened mobile phones were contaminated by microbial isolates, and the highest proportions of all microbial (clinical) isolates were recorded by gram+ve Bacillus spp (66\%) and gram-ve Pseudomonas spp (56\%) while the lowest proportions were recorded by beta-hemolysis Staphylococcus aureus (8\%) and Candida spp (12\%) as shown in the Fig. 1.

Additionally, there was a big difference in the kinds of bacterial isolates between the samples that collected from the health care workers mobile phones and that collected from the mobile phone of the University of Basrah employments, in the latter, there was no (Staphylococcus aureus) while the same isolate present in $8 \%$ of the mobile phone of the health care worker who in the same time had no nonhemolytic Staphylococcus epidermidis or candida spp. which appeared in $16 \%$ and $12 \%$ of the employee's mobile phones respectively. Furthermore, there were other pathogenic isolates appear in mobile phones for both the health care workers and the University of Basrah employments in a different percent as shown in Fig. 2.

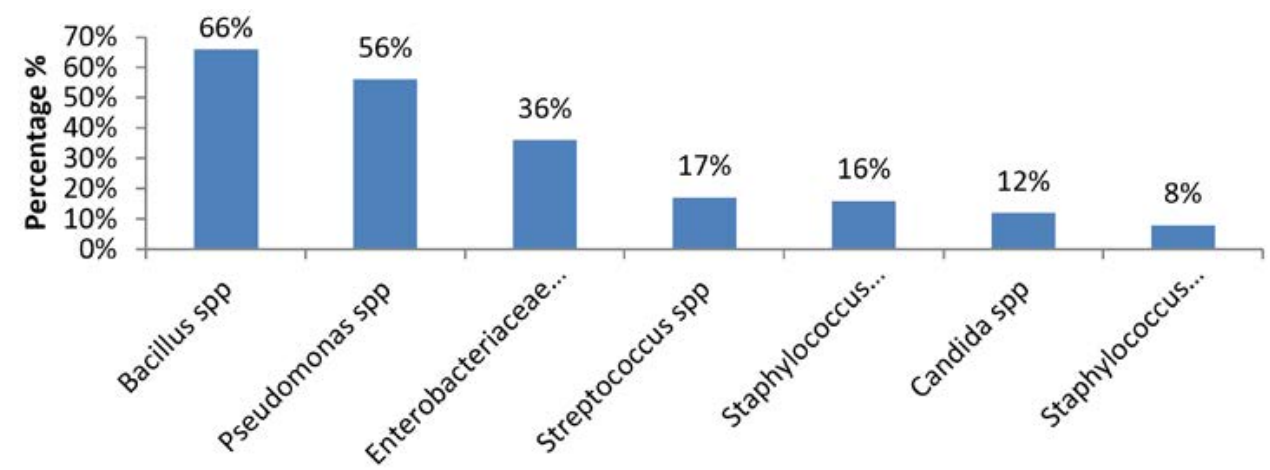

Bacterial isolates

Fig. 1. percent of the microbial isolates in all the samples of mobile phones.

Table 1. Antibiotic susceptibility for some microbial species that are isolated from mobile phones

\begin{tabular}{lccccc}
\hline \multirow{2}{*}{ Drug tested } & \multicolumn{5}{c}{ Antibiotic susceptibility for Microbial isolates } \\
\cline { 2 - 5 } & $\begin{array}{c}\text { Staphylococcus } \\
\text { aureus }\end{array}$ & $\begin{array}{c}\text { Proteus } \\
s p .\end{array}$ & $\begin{array}{c}\text { Klebsiella } \\
s p .\end{array}$ & $\begin{array}{c}\text { Citrobacter } \\
\text { sp. }\end{array}$ & $\begin{array}{c}\text { Salmonella } \\
s p .\end{array}$ \\
\hline CTX & $($ I) & (R) & (S) & (S) & $($ I) \\
CN & (I) & (S) & (S) & (S) & (S) \\
AX & (S) & (S) & (S) & (I) & (S) \\
SXT & (S) & (I) & (R) & (I) & (S) \\
ZOX & (S) & (R) & (I) & (I) & (S)
\end{tabular}

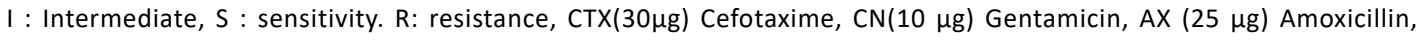
SXT $(1.25+23.75 \mu \mathrm{g})$ Trimethoprim +Sulfamethoxazole , Zox $(30 \mu \mathrm{g})$ Cefatizoxime. 
Also, the biochemical test for the Enteric bacteria that isolated from the health care workers and University of Basrah employments mobile phone show the presence of the following percent of the Enterobacteriaceae species as shown in Fig. 3.

And the statistical analysis as well as the columns for the percent of each kind of microbes in Fig. 2 show a significant difference in the percent of microbes isolated from the mobile phone for both groups of people.

The antibiotic susceptibility for 9 isolates of Enterobacteriaceae sp. and 2 isolates of Staphylococcus aureus show the presence of the Cefotaxime and Cefatizoxime resistance Proteus $s p$. as well as Trimethoprim + Sulfamethoxazole resistance Klebsiella sp.and also the intermediate susceptibility to the different antibiotic, was shown in all the isolates as displayed in Table 1 and the similar results for the similar isolates were not reported again.

\section{DISCUSSION}

Today the mobile phones become a piece of the more necessary equipment to professional and social life, and because the private property for mobile phone habits like existence attached closely to a human body part such as the hands, ears, nose, face which already carries multiple kinds of bacteria, that made the mobile phone a good reservoir for microbial pathogens and that is trying to focus on all kinds of bacterial isolated from the mobile phones especially pathogenic isolates and testing the antibiotic sensitivity for some of

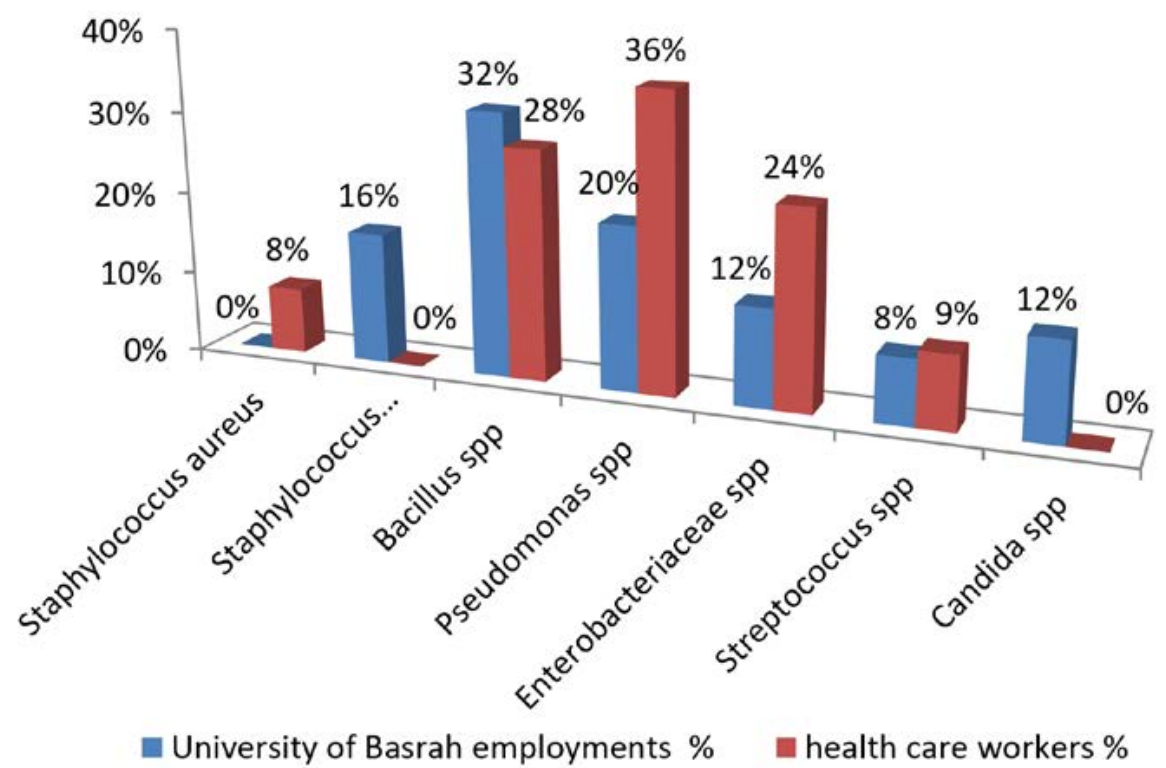

Fig. 2. The percentage of microbial isolates in the health care workers' mobile phone and the Basrah University employments.
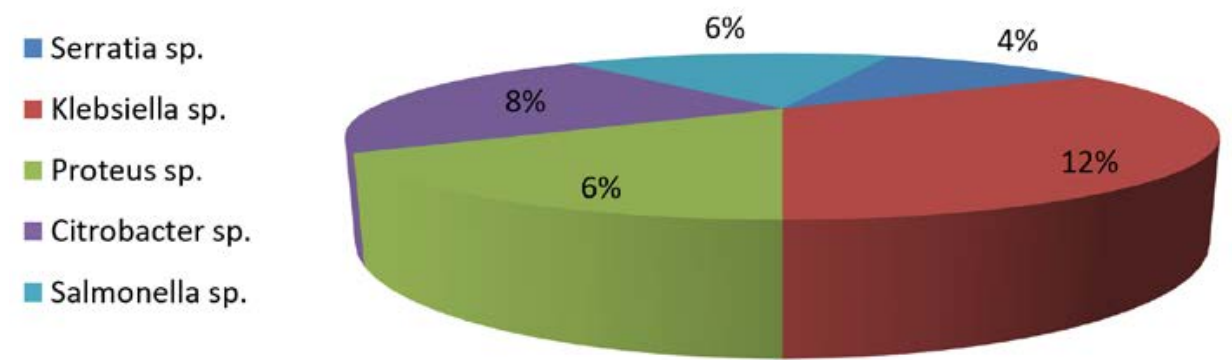

Fig. 3. The percentage of each Enterobacteriaceae spp. present in mobile phones. 
them to find out the antibiotic resistance isolates because the later hurt the people healthiness and to change the thought of lots of people that microbes only exist in the clinics and hospitals or research labs and thus they have a false sense of safety in other places, actually bacteria are practically found everywhere ${ }^{14}$. And that explains the presence of microbial contamination in all screened mobile phone also in the current study. Bacillus spp. form the highest proportions of all bacterial (clinical) isolates that isolated from the mobile phones and that's due to the nature of this genus which is one of the largest and most ubiquitous spores forming bacteria and Bacillus spp. are in many instances considered to be contaminants within clinical samples, It is therefore critical for the clinical staff to be alert to any sudden increases in isolation rates ${ }^{15,16}$. Also, several Bacillus species is a normal flora in the cooked food, cereals, and vegetables like Bacillus cereus ${ }^{17}$. The second highest prevalence bacterial isolate in the screened mobile phone was pseudomonas spp. which appear in the health care workers mobile phones in elevation percent rather than that of the university of Basrah employments generally because the genus of Pseudomonas is ecologically one the more various significant set of identified bacteria they are found in natural habitats, also pseudomonas spp. like Pseudomonas aeruginosa responsible for numerous events have been associated with defective or unhygienic medical equipment, workers also cross-contamination, and cross-colonization has been documented at the hospitals ${ }^{18.19}$. The presence of Enterobacteriaceae spp. in the volunteers' mobile phone in a high percentage was shows poor hygiene and that could be the main source of contamination ${ }^{20}$. The counts of these microbial groups may be used to evaluate handling and hygiene practices, as well as exposure of the cell phones ${ }^{21}$. And we can see that the percent of enteric bacteria in the mobile phone of the health care worker was the double of that of the employments and that can be attributed to the fact that the contamination of health care worker mobile phones by microorganisms can be done quickly and easily from the medical devices patients and all the environment of the hospital ${ }^{3}$. Within the current study, the biochemical study for the Enteric bacteria in the screened mobile phones was contained Serratia sp., Citrobacter sp. Salmonella sp., Klebsiella sp., and Proteus $s p$. and that partially agreed with the (Coscova et al 2018) study who informed the Citrobacter freundii and Klebsiella pneumonia presence within tested mobile phones, also several studies indicated that most common microorganisms isolated from health care workers mobile phones include Klebsiella pneumonia, Enterobacter species, coagulase-negative Staphylococcus, $S$. aureus, Bacillus species, Acinetobacter species, Pseudomonas species, Neisseria species, Serratia spp, Escherichia coli, Enterococcus feacalis, and Proteus Vulgaris [Karabay et al., 2007; Kilic et al., 2009; Teng et al., 2009, Chawla et al., 2009; Gunasekara et al., 2009, Girma 2015] and that excessively resemble our study results $s^{3,14,20,22-24}$.

Also, the Candida species can be seen in the mobile phone of the employments that's because Yeasts are the portion of body normal micro-flora and invasive infections only happened when immune function weakness occurs or there is a barrier leakage, and candida sp. reported as a contaminant of the mobile phone in some study like ${ }^{10,25-27}$.

Despite that the $S$. aureus, as well as $S$. epidermidis reported as the highest percent of isolates, appeared in the screened mobile in many studies like, and a large number of other studies, that in the current study we can see a recession in this percent to only $8 \%$ of the health care workers mobile phone and $0 \%$ in employments mobile phone of and that may be attributed to many reasons like increase awareness about contamination of device by pathogenic isolates especially the mobile phone and the ability of transmission of this isolates by them, also photographic notices like posters plus leaflets for motivation to adherence of self and hands hygiene. As well as all the studies which spotlight the pathogens' ability to live on the mobile phone surface, which can be involved a good control for the infection and minimize the appearance of pathogenic isolates in mobile phone $e^{7,27,28}$.

In the current study, some isolates like $S$. aureus and Enterobacteriaceae sp. which are common bacteria that spread in healthcare facilities and the community and can cause difficult-to-treat infections because of resistance to some antibiotics, therefore, the antibiotic susceptibility was tested and shows 
the existence of the Cefotaxime and Cefatizoxime resistance Proteus sp. as well as Trimethoprim + Sulfamethoxazole resistance Klebsiella sp.and that because the Proteus sp. and the Klebsiella sp are Enterobacteriaceae and some other gram-negative pathogens became highly $\beta$-Lactamase producing bacteria ${ }^{4,29}$. And also in this study the intermediate susceptibility to the different antibiotic was shown in all the isolates and that may be related to the origin of the isolates especially that found in the health care workers mobile phone who have frequently used the mobile phone during working for hours and are not properly disinfected and close contact with the patients who are mostly the source of the resistance and intermediate isolates especially in the developing countries because of the high level of ignorance, poverty, and bad hygienic applies, and there is a high commonness of counterfeit and illegal drugs of poor quality in circulation and also antibiotic up-use from prescription-dispensing to the patient in Iraq the antibiotics are purchased without a prescription as part of common practice, which leads to misuse of antibiotics by the public ${ }^{30,31}$.

And from this study and statistical analysis, we can see a significant difference in the type and percent of the pathogenic bacterial isolates which were reflex the difference in the pattern of life, nature of works, cleaning habit, using of disinfectant and many other characters between the healthcare workers and employments ${ }^{14}$. In the future, this study can be developed by expanded the research to include more number of screening mobile phones of people of different ages and degrees of education in Basra university or in hospitals. Also doing genetic identification of bacterial isolates as well as genomic study for the antibiotic-resistant bacteria.

\section{CONCLUSIONS}

The mobile phones today have become one of the most necessary types of equipment for social life, and all the mobile phone for all peoples can be contaminated by various kinds of bacterial isolates that some of these isolates can be resistance to specific antibiotics that may cause human infection, especially that contaminated the healthcare workers mobile phone, and the current study show a significant difference in the percent and kinds of bacterial isolate between the health care worker and people who work out of this field.

\section{ACKNOWLEDGMENTS}

We would like to express thanks to all people either from the medical staff of Al-Sadr Teaching Hospital or the University of Basrah employments for participation and for the Pharmacy college for financial support.

\section{CONFLICT OF INTERESTS}

The authors declare that there is no conflict of interest.

\section{AUTHORS' CONTRIBUTION}

All authors designed the experiments. A-URM performed the experiments. A-URM, AZG and A-JRA. analyzed the data and wrote the manuscript. All authors read and approved the manuscript.

\section{FUNDING}

This study was supported by the dean of the pharmacy college/ University of Basrah. The funders had no role in study design, data collection and analysis, decision to publish or preparation of the manuscript.

\section{DATA AVAILABILITY}

All datasets generated or analyzed during this study are included in the manuscript.

\section{ETHICS STATEMENT}

This article does not contain any studies with human participants or animals performed by any of the authors.

\section{REFERENCE}

1. Lee SY, Lee SY. Assessment of bacterial contamination of mobile phones of dentists and dental hygienists by Illumina MiSeq. Oral Biology Research. 2019;43(1):6065. doi: 10.21851/obr.43.01.201903.60

2. Zakai S, Mashat A, Abumohssin A, et al. Bacterial contamination of cell phones of medical students at King Abdulaziz University, Jeddah, Saudi Arabia. Journal of Microscopy and Ultrastructure. 2016;4(3):143. doi: 10.1016/j.jmau.2015.12.004

3. Mobile-cellular subscriptions per 100 inhabitants in Iraq 2002-2018. https://www.statista.com/ statistics/509495/mobile-cellular-subscriptions- 
per-100- inhabitants-in-iraq/.

4. Bodena D, Teklemariam Z, Balakrishnan S, Tesfa T. Bacterial contamination of mobile phones of health professionals in Eastern Ethiopia: Antimicrobial susceptibility and associated factors. Tropical Medicine and Health. 2019;47(1):1-10. doi: 10.1186/s41182019-0144-y.

5. Ilusanya OAF, Adesanya OO, Adesemowo A, Amushan NA. Personal Hygiene and Microbial Contamination of Mobile Phones of Food Vendors in Ago-Iwoye Town, Ogun State, Nigeria. Pak J Nutr (PJN). 2012;11(3):276278. doi: 10.3923/pjn.2012.276.278

6. Anuradha S, Arunkumar S, Tan chan W, Joyce Heng W, Goh Yi W. Identification of Bacterial Contamination and Evaluation of Antimicrobial Solution on Mobile Phones. Journal of Pharmaceutical Microbiology. 2018;4(1):36.

7. Auhim HS. Bacterial Contamination of Personal Mobile Phones in Iraq Bacterial Contamination of Personal Mobile Phones in Iraq Husam Sabah Auhim Corresponding author: Husam Sabah Auhim; Department of Biology, College of Science, 2014.

8. Digestive Ferments Company. Difco Laboratories, D. Difco manual of dehydrated culture media and reagents for microbiological and clinical laboratory procedures, 1953;9th ed. Detroit. https://www. biodiversitylibrary.org/item/30998

9. Salih MK, Alrabadi NI, Thalij KM, Hussien AS. Isolation of Pathogenic Gram-Negative Bacteria from Urinary Tract Infected Patients. Open Journal of Medical Microbiology. 2016;06(2):59-65. doi: 10.4236/ ojmm.2016.62009.

10. Selim HS, Abaza AF. Microbial contamination of mobile phones in a health care setting in Alexandria, Egypt. GMS Hygiene and Infection Control. 2015;10:21965226. doi: $10.3205 /$ dgkh000246

11. Sagar A. Oxidase Test- Principle, Uses, Procedure, Types, Result Interpretation, Examples, and Limitations. 2018. https://microbiologyinfo.com/oxidase-testprincipleuses-procedure-types-result-interpretation-examplesand-limitations.

12. Collee G, Marmion BP, Fraser AG, Simmons A. Mackie and McCartney Practical Medical Microbiology (14thed.) Churchill Livingstone. New York. 1996:245261.

13. Joob B, Wiwanitkit V. Comment on: "High level bacterial contamination of secondary school students' mobile phones". Germs. 2017;7(3):153. doi: 10.18683/ germs.2017.1121

14. Koscova J, Hurnikova Z, Pistl J. Degree of bacterial contamination of mobile phone and computer keyboard surfaces and efficacy of disinfection with chlorhexidine digluconate and triclosan to its reduction. Int J Environ Res Public Health. 2018;15(10):2238. doi: 10.3390/ijerph15102238

15. Glasset B, Herbin S, Granier SA, et al. Bacillus cereus, a serious cause of nosocomial infections: Epidemiologic and genetic survey. PLOS ONE. 2018;13(5):1-19. doi: 10.1371/journal.pone.0194346

16. BIOHAZ. EP on BH. Risks for public health related to the presence of Bacillus cereus and other Bacillus spp. including Bacillus thuringiensis in foodstuffs. EFSA Journal. 2016;14(7):e04524. doi: 10.2903/j. efsa.2016.4524

17. Tewari A, Abdullah S. Bacillus cereus food poisoning: international and Indian perspective. Journal of Food Science and Technology. 2015;52(5):2500-2511. doi: 10.1007/s13197-014-1344-4.

18. Raposo A, Perez E, de Faria CT, Ferrus MA, Iruzubieta CC. Food Spoilage by Pseudomonas spp.- An Overview. In Foodborne Pathogens and Antibiotic Resistance. 2017:41-71. doi: 10.1002/9781119139188.ch3.

19. Iversen BG, Jacobsen T, Eriksen H-M, et al. An Outbreak of Pseudomonas aeruginosa Infection Caused by Contaminated Mouth Swabs. Clin Infect Dis. 2007;44(6):794-801. doi: 10.1086/511644

20. Girma G. Potential Health Risks with Microbial Contamination of Mobile phones. Glob Res J Educ. 2015;3(1):246-254.

21. Martinez-Gonzales NE, Solorzano-Ibarra F, CabreraDiaz E, et al. Microbial contamination on cell phones used by undergraduate students . Canadian Journal of Infection Control. 2017;32(4):211-216.

22. Karabay O, Kocoglu E, Tahtaci M. The role of mobile phones in the spread of bacteria associated with nosocomial infections. J Infect Dev Ctries. 2007;1(1):72-73.

23. Gunasekara TDCP, Kudavidanage BP, Peelawattage $\mathrm{MK}$, et al. Bacterial Contamination of Anaesthetists Hands, Personal Mobile Phones and Wrist Watches used during Theatre Sessions. Sri Lankan Journal of Anaesthesiology, 2009;17(1):11-15. doi: 10.4038/slja. v17i1.409

24. Chawla K, Mukhopadhayay C, Gurung B, Bhate P, Bairy I. Bacterial "Cell" phones: Do cell phones carry potential pathogens? Online Journal of Health and Allied Sciences. 2009;8(1):1-5. http://cogprints. org/6566/.

25. Kordecka A, Krajewska-Kulak E, Lukaszuk C, Kraszynska B, Kulak W. Isolation frequency of Candida present on the surfaces of mobile phones and handsx. $B M C$ Infectious Diseases. 2016;16(1):1-7. doi: 10.1186/ s12879-016-1577-0.

26. Jalalmanesh S, Darvishi M, Rahimi M, Akhlaghdoust M. Contamination of senior medical students' cell phones by nosocomial infections: A survey in a universityaffiliated hospital in Tehran. Shiraz E Medical Journal. 2017;18(4). doi: 10.5812/semj.43920

27. El-Ashry MA, ElSheshtawy NM. Mobile Phones are Silent Threat. Int J Curr Microbiol Appl Sci. 2015;4(11):199-205.

28. Ulger F, Esen S, Dilek A, Yanik K, Gunaydin M, Leblebicioglu $\mathrm{H}$. Are we aware of how contaminated our mobile phones with nosocomial pathogens? Ann Clin Microbiol Antimicrob. 2009;8:4-7. doi: 10.1186/1476-0711-8-7.

29. Majeed HT, Aljanaby AAJ. Antibiotic Susceptibility Patterns and Prevalence of Some Extended Spectrum Beta-Lactamases Genes in Gram-Negative Bacteria Isolated from Patients Infected with Urinary Tract Infections in Al-Najaf City, Iraq. Avicenna J Med Biotechnol. 2019;11(2):192. https://pubmed.ncbi.nlm. nih.gov/31057723/. 
30. Mohammed AG, Al-Aaragi ANH, Merzah MA Knowledge, attitude, and practice regarding diabetic mellitus among a sample of students at the technical institute of Karbala. Medical Journal of Babylon. 2018;15(2): 164-168. doi: 10.4103/MJBL.MJBL_38_18.
31.

Al Momani W, Khatatbeh M, Altaany Z. Antibiotic susceptibility of bacterial pathogens recovered from the hand and mobile phones of university students. Germs. 2019;9(1):9. doi: 10.18683/germs.2019.1152. 